\title{
Hyaluronan and type III procollagen peptide concentrations in bronchoalveolar lavage fluid in idiopathic pulmonary fibrosis
}

\author{
L BJERMER，R LUNDGREN，R HÄLLGREN \\ From the Department of Pulmonary Medicine, University Hospital, Umeå, and the Department of Internal \\ Medicine, University Hospital, Uppsala, Sweden
}

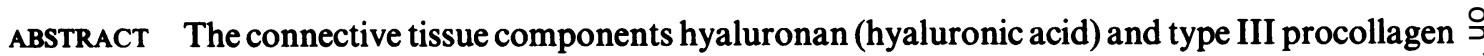
peptide were measured in bronchoalveolar lavage fluid in 22 patients with idiopathic pulmonary $\vec{T}$ fibrosis and 21 healthy control subjects. The patients with idiopathic pulmonary fibrosis had higher $\frac{\mathbb{D}}{\mathbb{C}}$ concentrations of hyaluronan (median $46 \mu \mathrm{g} / \mathrm{l}$ ) and type III procollagen peptide (median $0.45 \mu \mathrm{g} / \mathrm{l}$ ) than the healthy controls $(9$ and $<0.2 \mu \mathrm{g} / \mathrm{l} ; \mathrm{p}<0.001)$. The patients had normal serum concentrations of hyaluronan and of the procollagen peptide, and albumin concentrations in lavage $\vec{\varphi}$ fluid similar to those of the control subjects. Neutrophil and lymphocyte counts in lavage fluid were $0_{0}^{\circ}$ increased on average 10 and two fold respectively in the patients with idiopathic pulmonary fibrosis 0 and both correlated with the amount of hyaluronan recovered $(p<0.05)$. An inverse correlation was seen between the transfer factor for carbon monoxide and hyaluronan concentrations in lavage fluid $\frac{}{0}$ in the patients $(\mathrm{p}<0.05)$. Deterioration in lung function and radiographic progression were seen $\stackrel{0}{\%}$ over six months in 12 of the patients. These patients had higher lavage fluid concentrations of $\stackrel{\varnothing}{\varnothing}$ hyaluronan and type III procollagen peptide than the patients whose disease was stable $(\mathrm{p}<0.01)$. $\overrightarrow{\overrightarrow{0}}$ Increased synthesis of hyaluronan and type III procollagen peptide in lung parenchyma may reflect activation or proliferation (or both) of pulmonary fibroblasts in idiopathic pulmonary fibrosis and seems to be linked to the severity and activity of the lung disease.

\section{Introduction}

The destruction of the lung parenchyma in idiopathic pulmonary fibrosis (cryptogenic fibrosing alveolitis) appears to be mediated in part by inflammatory cells infiltrating the alveolar-capillary membrane and small airways..$^{1-3}$ The injury to parenchymal cells is associated with proliferation of fibroblasts and deposition of increased amounts of collagen in the interstitial space. The traditional investigations used to monitor the progression of idiopathic pulmonary fibrosis are chest radiography and pulmonary function tests, although from the point of view of prognosis it is probably more important to identify the lung lesions histologically. The finding of neutrophils in the

Address for reprint requests: Dr R Hällgren, Department of Internal Medicine, University Hospital, S-751 85 Uppsala, Sweden.

Accepted 11 November 1988 alveolar region in idiopathic pulmonary fibrosis suggests that the neutrophil has a pathogenetic role in this condition. ${ }^{45}$ Bronchoalveolar lavage may contribute to the understanding of the nature of idiopathic pulmonary fibrosis. Recovery of increased numbers of neutrophils in lavage fluid has been correlated with a worse prognosis of the disease. ${ }^{67}$ The mechanisms underlying the activation and proliferation of lung fibroblasts in idiopathic pulmonary fibrosis are not fully understood but inflammatory mediators are likely to be important. ${ }^{89} \mathrm{Apart}$ from lung biopsy there are few methods for assessing changes in the connective tissue of the lung in idiopathic pulmonary fibrosis. Recently we drew attention to the possible usefulness of determining concentrations of hyaluronan (according to older nomenclature hyaluronate or hyaluronic acid) and type III procollagen peptide in lavage fluid as potential markers of activated fibroblasts or an expanded fibroblast mass associated with interstitial fibrosis. ${ }^{10-13}$ We found increased lavage fluid concentra- 
tions in sarcoidosis and extrinsic allergic alveolitis, correlating with disease activity. We now report increased hyaluronan and type III procollagen peptide concentrations in lavage fluid from patients with idiopathic pulmonary fibrosis. Concentrations were related to the intensity of the alveolitis, as defined by the recovery of lavage fluid neutrophils and other inflammatory cells, and to the clinical severity, as indicated by pulmonary function tests and radiological criteria.

\section{Methods}

We evaluated 22 patients ( 16 men and six women) with idiopathic pulmonary fibrosis. Their mean age was 58 (range 33-78) years. Five patients were smokers. In 18 patients the diagnosis was based on a compatible history, physical examination, pulmonary function tests, and chest radiography. In four patients where there was some uncertainty the diagnosis was confirmed by open lung biopsy. None of the patients had cardiac dysfunction or connective tissue disease. Sarcoidosis was excluded by a negative response to the Kveim test and by the absence of epitheloid cell granulomas in biopsy specimens from bronchial mucosa, lung, or lymph nodes. Pneumoconiosis was excluded by lack of exposure to inorganic dust and extrinsic alveolitis by lack of exposure to organic dust and absence of precipitating antibodies in serum. Three of the patients with idiopathic pulmonary fibrosis were receiving prednisolone, $10-15 \mathrm{mg}$ a day, at the time of the investigation; two had stopped corticosteroid treatment more than a year before the study. The mean duration of symptoms at the time of the investigation was 18 months. Twenty one apparently healthy non-smoking volunteers (14 men, seven women) aged 19-61 served as controls.

Vital capacity (VC) and forced expiratory volume in one second $\left(\mathrm{FEV}_{1}\right)$ were measured with a Bernstein spirometer and diffusion capacity (TLCO, carbon monoxide transfer factor) by the single breath carbon monoxide technique. Results were expressed as percentages of predicted normal values. ${ }^{14} 15$ The $95 \%$ confidence intervals for the normal range in our laboratory are $\geqslant 80 \%$ of the predicted value for VC and $F E V_{1}$ and $\geqslant 75 \%$ for TLCo. All chest radiographs were read at the end of the study by one investigator, who was unaware of the results of lavage fluid analysis or of pulmonary function tests. Radiographs were scored according to the ILO 1981 International Classification of Radiographs of the Pneumoconioses. The ILO score has been shown to be useful in interstitial diseases, including idiopathic pulmonary fibrosis. ${ }^{1617}$

Before bronchoscopy patients and controls received atropine or scopolamine, usually combined with morphine or pethidine chloride, subcutaneously. The upper respiratory tract was anaesthetised with lignocaine hydrochloride. A fibreoptic bronchoscope (Olympus BF IT or BF 4B2, Tokyo) was wedged in the lingular segmental bronchus and $240 \mathrm{ml}$ sterile KrebsRinger phosphate buffer, $\mathrm{pH} 7 \cdot 3,37^{\circ} \mathrm{C}$, infused in boluses of $60 \mathrm{ml}$. The fluid was gently aspirated immediately after each instillation. The lavage fluid was kept on ice and passed through a nylon filter (pore diameter $100 \mu \mathrm{m}$, Syntab Products AB, Malmö, Sweden). The cells were then collected by centrifugation at $400 \mathrm{~g}$ for 15 minutes. The supernatant was frozen at $-70^{\circ} \mathrm{C}$ until analysis in sequence. The cells were gently resuspended in balanced salt solution to a concentration of $10^{6} \mathrm{cells} / \mathrm{ml}$, excluding epithelial cells. Cytocentrifuge (Cytospin Shandon, Southern Products Ltd, Runcorn) preparations, $5 \times 10^{4}$ nonepithelial cells per slide, were stained with May-Grünwall-Giemsa before differential counting. Mast cells were stained with acid toluidine blue and counterstained with Mayers acid haematoxylin. Lymphocyte, neutrophil, eosinophil, and macrophage numbers were expressed both as percentages of 200 cells (except epithelial cells) and as actual lavage fluid concentrations. Mast cells were counted as the number present in 10 visual fields with $\times 16$ magnification and expressed as a percentage of all non-epithelial cells.

Hyaluronan concentrations were determined in duplicate in serum and lavage fluid by a modified radioassay (Pharmacia Diagnostics, Uppsala, Sweden).$^{1018}$ Both tests are based on the use of specific hyaluronan binding proteins isolated from bovine cartilage. In the modified test the hyaluronan from the samples $(100 \mu \mathrm{l})$ is allowed to bind to hyaluronan binding proteins labelled with iodine- 125 in solution for 60 minutes. The unbound ${ }^{125} \mathrm{I}$ binding proteins are then quantified by incubating with hyaluronan covalently coupled to Sepharose particles of small size and low density. Separation of particles is performed by centrifugation ( $1500 \mathrm{~g}$ for 10 minutes) followed by decanting. The radioactivity bound to the particles is then measured. The within assay variation was $4 \cdot 5-6.5 \%$ and the between assay variation $4 \cdot 8-8 \cdot 5 \%$. The specificity of the assay applied to lavage fluid was proved by dilution and recovery experiments, which showed parallelism to the standard curve and complete recovery of added hyaluronan. The two techniques give identical results in serum and lavage fluid. The normal concentration of hyaluronan in serum $(\mathrm{n}=80)$ is 49 (SD 33) $\mu \mathrm{g} / \mathrm{l}$. The type III procollagen aminoterminal peptide related antigens were assayed by radioimmunoassay (Behringwerke AG, Marburg, Germany). ${ }^{11}{ }^{19}$ In our laboratory the normal serum concentration of procollagen peptide $(\mathrm{n}=111)$ is $15.4(\mathrm{SD} 2.2) \mu \mathrm{g} / \mathrm{l}$. The variability of the method was less than $12 \%$. Serial dilution of lavage fluid samples from patients with idiopathic pulmonary 
fibrosis gave inhibition curves similar to those of the standard and very similar to those recently presented, with the same radioimmunoassay, for lavage fluid from patients with idiopathic pulmonary fibrosis. ${ }^{20}$ The detection limit for hyaluronan was $5 \mu \mathrm{g} / 1$ and for procollagen peptide $0.2 \mu \mathrm{g} / \mathrm{l}$. When either was undetectable the detection limit was used in the calculations. Albumin was measured by fluorescence nephelometry (Multistat III, Instrumental Laboratory, Lexington, Montana).

The protocol of this study was agreed by the local ethics committee and the study was performed with the free and informed consent of all volunteers and patients.

The statistical significance of differences between groups was tested by the Wilcoxon rank sum test and correlation coefficients were determined with Spearman's test.

\section{Results}

LAVAGE FLUID CONTENT OF HYALURONAN AND TYPE III PROCOLLAGEN PEPTIDE (figure)

The concentration of hyaluronan in the lavage fluid was higher in patients with idiopathic pulmonary fibrosis (median 46, range 12-437 $\mu \mathrm{g} / \mathrm{l}$ ) than in healthy controls $(9$, range $<5-23 \mu \mathrm{g} / \mathrm{l})(\mathrm{p}<0.001)$. The median lavage fluid concentration of type III $\stackrel{\vec{\rho}}{\rightarrow}$ procollagen peptide was also higher in the patients with idiopathic pulmonary fibrosis $(0.45$, range 0.2 - 들 $12.2 \mu \mathrm{g} / \mathrm{l})$ than in the control patients, whose values $\frac{5}{5}$ which were all less than the detection limit $(0 \cdot 2 \mu \mathrm{g} / 1) \stackrel{\mathbb{\Phi}}{\propto}$ $(p<0.001)$. There was a significant relation between lavage fluid concentrations of hyaluronan and type III ${ }^{\circ}$ procollagen peptide in the patients with idiopathic $\stackrel{\circ}{\circ}$ pulmonary fibrosis $(\mathrm{r}=0.53, \mathrm{p}<0.02)$. The $\overrightarrow{\vec{\omega}}$ hyaluronan and procollagen peptide concentrations in ${ }_{\sigma}^{\omega}$ patients were independent of age, sex, and smoking $\overrightarrow{\vec{x}}$ history. Values in the three patients receiving corticosteroid treatment at the time of bronchoscopy did not differ consistently from those in the other patients (fig). The serum concentrations of hyaluronan and $\vec{N}$ type III procollagen peptide were within the normalo ranges for all patients. The median recovery of albumin during lavage was 62 (range 34-219) $\mathrm{mg} / \mathrm{l}$ for 7 the patients and 45 (range $16-91) \mathrm{mg} / \mathrm{l}$ for the controls $\frac{\mathbb{O}}{\mathrm{O}}$ $(p<0.05)$.

\section{RELATION TO PULMONARY FUNCTION AND}

PULMONARY RADIOLOGICAL CRITERIA

In the patients with idiopathic pulmonary fibrosis the

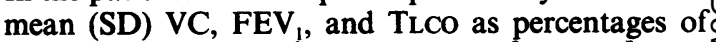
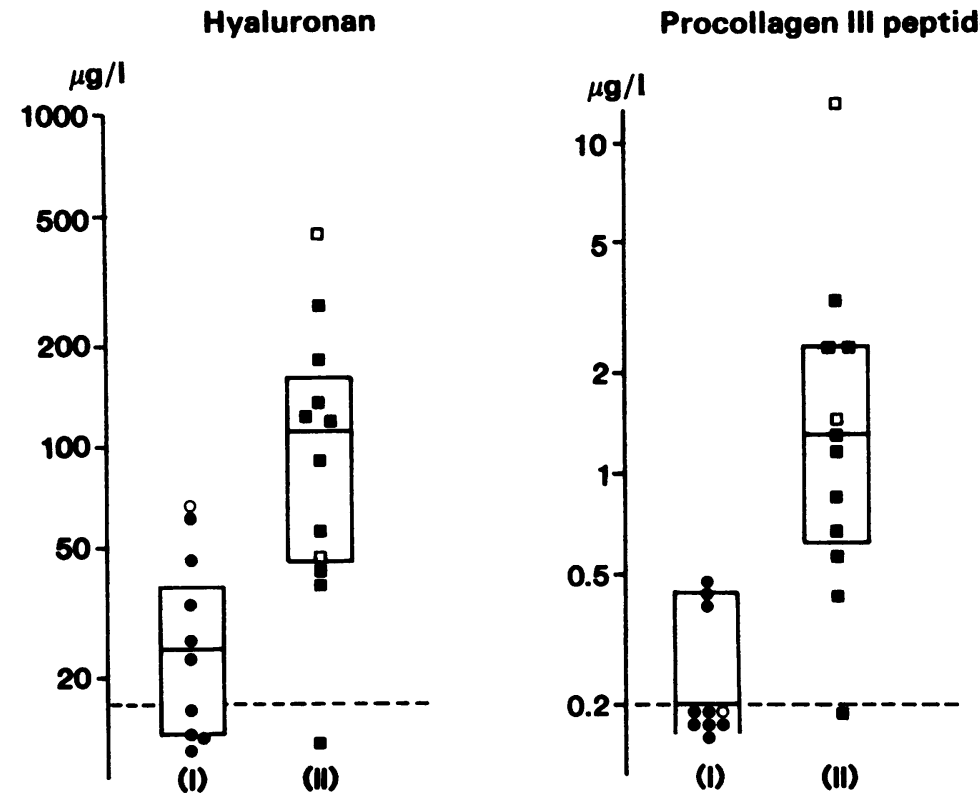

Lavage fluid concentrations of hyaluronan and type III procollagen peptide in patients with idiopathic pulmonary fibrosis. The patients were grouped with respect to the outcome over six months: I-patients with stable disease; II-patients with clinical impairment. Three patients (indicated by $\bigcirc$ or $\square$ ) were being treated with corticosteroids at the time of bronchoalveolar lavage. Medians and lower and upper quartiles are illustrated as box plots. - - - indicates the upper normal concentrations for hyaluronan and procollagen III peptide in lavage fluid. 
Table 1 Bronchoalveolar lavage cellular constituents in patients with idiopathic lung fibrosis (medians with lower and upper quartiles in parentheses)

\begin{tabular}{|c|c|c|c|c|c|c|c|c|}
\hline & \multirow[b]{2}{*}{$n$} & \multirow{2}{*}{$\begin{array}{l}\text { Total } \\
\text { cells } \\
\left(\times 10^{\top} / l\right)\end{array}$} & \multicolumn{2}{|l|}{ Macrophages } & \multicolumn{2}{|l|}{ Lymphocytes } & \multicolumn{2}{|l|}{ Neutrophils } \\
\hline & & & $\left(\times 10^{7} / l\right)$ & $(\%)$ & $\left(\times 10^{7} / \mathrm{l}\right)$ & $(\%)$ & $\left(\times 10^{7} / l\right)$ & $(\%)$ \\
\hline $\begin{array}{l}\text { Patients } \\
\text { Controls }\end{array}$ & $\begin{array}{l}22 \\
21\end{array}$ & $\begin{array}{l}8 \cdot 0(5 \cdot 0-11 \cdot 8) \\
6 \cdot 4(5 \cdot 0-8 \cdot 0)\end{array}$ & $\begin{array}{l}6.5(3.5-7.5) \\
5.5(4.4-7.0)\end{array}$ & $\begin{array}{l}56(34-69) \\
92(82-95)\end{array}$ & $\begin{array}{l}1.5(0.7-2.3) \\
0.4(0.2-0.7)\end{array}$ & $\begin{array}{c}17(11-32) \\
6(4-14)\end{array}$ & $\begin{array}{l}1.0(0.2-2.2) \\
0.06(0.0-0.1)\end{array}$ & $\begin{array}{l}10(3.0-23) \\
1.0(0.0-2.0)\end{array}$ \\
\hline
\end{tabular}

predicted values were 74 (14), 79 (15), and 52 (14). When these were compared with hyaluronan and type III procollagen peptide concentrations the only significant correlation was between lavage fluid hyaluronan and TLCO $(r=-0.48, p<0.05)$.

The mean chest radiograph score of the patients with idiopathic pulmonary fibrosis was $1.5 / 1.5$ (range 1/0-3/2). A significant correlation was observed between lavage fluid type III procollagen peptide and radiographic score $(r=0.54, p<0.02)$.

\section{RELATION TO RECOVERY OF INFLAMMATORY} CELLS

The cells recovered by lavage in patients with idiopathic pulmonary fibrosis and control subjects are shown in table 1 . The total cell count was slightly increased in the patients $(p<0.05)$. The patients had an absolute and relative increase in the number of lymphocytes and neutrophils ( $p<0.001$ ); the percentage of macrophages was diminished though the absolute number was slightly increased. Eosinophils and mast cells were rarely detected in healthy controls and never exceeded $1 \%$ of the total count. In the patients the median recovery of eosinophils was $4 \%$, range $0-49 \%(p<0.001)$. An increased recovery of mast cells was also seen in the patients $(p<0.001)$; the median mast cell count was $1 \cdot 4 \%$ (range $0 \cdot 1-10 \%$ ).

The lavage fluid concentration of hyaluronan was related to the number of neutrophils recovered ( $r=0.50$ for the absolute cell number and 0.49 for the relative cell number) $(p<0.05)$. The hyaluronan in the lavage fluid was also correlated $(p<0.05)$ with the absolute and relative lymphocyte number $(r=0.51$ and $0 \cdot 45$ ). No relation was seen between the recovery of hyaluronan and the other cell types. Type III procollagen peptide in the lavage fluid did not correlate with any cell variable.
RELATION TO PROGRESSION OF LUNG DISEASE

Deterioration of lung function - that is, a reduction in VC of more than $10 \%$ or a reduction in TLCO of more than $15 \%$ and progression of chest radiograph changes - was observed over six months in 12 of the 22 patients with idiopathic pulmonary fibrosis. These patients had a lavage fluid concentration of hyaluronan $(p<0.01)$ and type III procollagen peptide nearly six times those of the patients with static disease $(p<0.01$; fig). Patients with progressive disease also had increased numbers of neutrophils, lymphocytes, eosinophils, and mast cells but the differences were not significant (table 2).

\section{Discussion}

The finding that bronchoalveolar lavage fluid from patients with idiopathic pulmonary fibrosis contained increased concentrations of hyaluronan and type III procollagen peptide extends our previous observations on the altered metabolism of connective tissue components in interstitial lung disease. ${ }^{10-13}$ The average recovery of hyaluronan and procollagen peptide in lavage fluid from patients with idiopathic pulmonary fibrosis was similar to that in sarcoidosis, ${ }^{1012}$ but less than $10 \%$ of that recovered in the acute phase of extrinsic allergic alveolitis. ${ }^{13}$ The present results for type III procollagen peptide in patients with idiopathic pulmonary fibrosis support previous findings in a similar group of patients. ${ }^{20-22}$

Most of the hyaluronan in the healthy lung is localised in perivascular and peribronchial tissue. ${ }^{23}$ It has been claimed that hyaluronan is the major glycosaminoglycan of the interstitium ${ }^{24}$ and during bleomycin induced alveolitis and fibrosis in the rat large amounts of hyaluronan appear in this compartment. ${ }^{23}$ It is produced by most cells but in particularly

Table 2 Cellular constituents of lavage fluid in patients with idiopathic pulmonary fibrosis grouped with respect to the progression of lung disease (medians with lower and upper quartiles in parentheses)

\begin{tabular}{|c|c|c|c|c|c|c|}
\hline & $n$ & $\begin{array}{l}\text { Macrophages } \\
\left(\times 10^{5} / l\right)\end{array}$ & $\begin{array}{l}\text { Lymphocytes } \\
\left(\times 10^{7} / l\right)\end{array}$ & $\begin{array}{l}\text { Neutrophils } \\
\left(\times 10^{\prime} / l\right)\end{array}$ & $\begin{array}{l}\text { Eosinophils } \\
\left(\times 10^{\prime} / l\right)\end{array}$ & $\begin{array}{l}\text { Mast cells } \\
\left(\times 10^{5} / l\right)\end{array}$ \\
\hline $\begin{array}{l}\text { Stationary disease } \\
\text { Progressive disease }\end{array}$ & $\begin{array}{l}12 \\
10\end{array}$ & $\begin{array}{l}4 \cdot 3(2 \cdot 9-6 \cdot 1) \\
3 \cdot 1(2 \cdot 6-5 \cdot 6)\end{array}$ & $\begin{array}{l}1.1(0.4-1.4) \\
1.9(1.5-2.8)\end{array}$ & $\begin{array}{l}0.43(0.12-1 \cdot 70) \\
1.32(0.37-2.45)\end{array}$ & $\begin{array}{l}0.23(0.07-0.51) \\
0.40(0.18-0.71)\end{array}$ & $\begin{array}{c}8.0(5 \cdot 5-17 \cdot 9) \\
19 \cdot 2(10 \cdot 2-36 \cdot 5)\end{array}$ \\
\hline
\end{tabular}


large amounts by activated fibroblasts, ${ }^{24-28}$ which also synthesise a major portion of lung collagen. ${ }^{29}$ A characteristic finding in patients with idiopathic pulmonary fibrosis is the increase in type III collagen in biopsy specimens. ${ }^{30}$ Procollagen type III is synthesised by fibroblasts as a precursor of collagen type III. ${ }^{31}$ Specific $N$ terminal and $C$ terminal procollagen peptides are split off in the extracellular space during the conversion into collagen. The propeptides are cleaved in amounts proportional to the amount of collagen, so that they are potential markers of collagen secretion. ${ }^{32}$ The present observation in idiopathic pulmonary fibrosis and previous findings in sarcoidosis ${ }^{33}$ and extrinsic alveolitis ${ }^{13}$ of a close association between the lavage recovery of hyaluronan and type III procollagen peptide suggest a common cellular origin for these markers of lung disease. The contribution of hyaluronan from the circulation to lavage fluid is negligible as the concentrations of hyaluronan in lavage fluid are similar to or higher than the normal circulating concentrations in patients with idiopathic pulmonary fibrosis. In contrast, type III procollagen peptide appears in lavage fluid in concentrations much lower than in the circulation. An increased passive leakage of the procollagen peptide across the bloodalveolar barrier might therefore influence the amount recovered in lavage fluid, although our patients with idiopathic pulmonary fibrosis had albumin concentrations in lavage fluid similar to those of the controls. Hyaluronan is likely to give a more reliable estimate than type III procollagen peptide of an enhanced local synthesis of connective tissue components. Another possible influence to be considered is the certainty of the diagnosis of idiopathic pulmonary fibrosis. On the basis of clinical characteristics we were convinced of the diagnosis in most patients and had to confirm it by open lung biopsy in only a few cases. With the lack of histological proof of idiopathic pulmonary fibrosis, however, incorrect diagnoses in some patients cannot be completely excluded.

In previous studies ${ }^{10133}$ in patients with sarcoidosis hyaluronan and type III procollagen peptide in lavage fluid were related to lung volume, diffusion capacity, and radiographic stage, providing indirect support for their potential as markers of a fibrotic process in the lung. In the present study their relation to physiological or radiographic estimates of the lung disease was not so evident, but significant correlations were found between increased hyaluronan concentrations and reduced diffusion capacity and between increased type III procollagen peptide concentrations and chest radiograph scores. In accordance with previous studies, ${ }^{21}$ we found no relation between the procollagen peptide and results of physiological tests of lung function. More apparent was the greater recovery of hyaluronan and the procollagen peptide in patients with idiopathic pulmonary fibrosis who deteriorated over six months than in those who had stable disease. Low and colleagues ${ }^{21}$ reported that patients with idiopathic pulmonary fibrosis and substantially raised type III procollagen peptide concen- $\bar{C}$ trations in lavage fluid had a more severe disease $\frac{\bar{\sigma}}{\bar{N}}$ clinically.

The mechanisms underlying the accumulation of $\vec{D}$ fibroblasts in the lungs of patients with idiopathic pulmonary fibrosis are largely unknown, but it is thought to be a consequence of alveolitis induced by macrophages, lymphocytes, neutrophils, and eosino- $\vec{\omega}$ phils. ${ }^{3}$ Idiopathic pulmonary fibrosis is characterised $\stackrel{\circ}{\circ}$ by an increased proportion of neutrophils in lavage $\overrightarrow{\vec{x}}$ fluid $^{26}$ and increased numbers of lymphocytes and eosinophils may also be present. ${ }^{6}$ An association $\stackrel{+}{\sim}$ between the presence of neutrophils in lavage fluid and subsequent deterioration in pulmonary function has $\widetilde{N}$ been reported. ${ }^{67} \mathrm{An}$ increase in eosinophils in lavage 을 fluid has also been linked to a bad prognosis. ${ }^{6}$ Our patients had an increase in the absolute and the relative number of neutrophils and eosinophils 음 Lymphocytosis was seen in some of the patients but the average lymphocyte number was only slightly greater than in the controls. The lavage fluid concen- $\vec{\theta}$ trations of hyaluronan were correlated with the num- $\infty$ bers of neutrophils and lymphocytes recovered. Thus the enhanced synthesis of hyaluronan in idiopathic pulmonary fibrosis seems to be linked to the intensity of the alveolitis. In vitro the production of hyaluronan from fibroblasts is greatly stimulated by growth $\frac{\circ}{\square}$

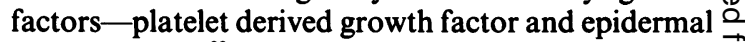
growth factor. ${ }^{28}$ Recently increased production of $\overrightarrow{\vec{O}}$ platelet derived growth factor by alveolar macro- 3 phages recovered from patients with idiopathic pulmonary fibrosis has been reported..$^{34}$ Other fibroblast activating substances known to stimulate hyaluronan production include interleukin- $1,{ }^{27}$ which may also be a factor in active alveolitis.

Several cellular and humoral tests have yielded $\frac{0}{3}$ correlations with high intensity alveolitis in patients with idiopathic pulmonary fibrosis. ${ }^{35-37}$ The present $O$ study has suggested that hyaluronan and type III procollagen peptide measurements in lavage fluid may $\stackrel{\circ}{5}$ also have a prognostic value in this disease; but further $\rightarrow$ studies are needed before they can be recommended for routine clinical use.

We thank Mrs Margit Tjernberg for skilful technical N assistance. This study was supported by grants $N$ from the Swedish Medical Research Council and $\underset{\sigma}{\sigma}$ the Swedish Association against Chest and Lung Diseases.

\section{References}

1 Crystal RG, Fulmer JD, Roberts WC, et al. Idiopathic $\square$ pulmonary fibrosis; clinical, histologic, radiographic, physiologic, scintigraphic and biochemical aspects.

Ann Intern Med 1976;85:769-88.
2 Reynolds HY, Fulmer JD, Kaymierowski JA, et al. Analysis of bronchoalveolar lavage fluid from patients with idiopathic pulmonary fibrosis and chronic hyper- 
sensitivity pneumonitis. J Clin Invest 1977;59:165-75.

3 Crystal RG, Bitterman PB, Rennard SI, Hance AJ, Keogh BA. Interstitial lung diseases of unknown cause. Disorders characterized by chronic inflammation of the lower respiratory tract. $N$ Engl J Med 1984; 310:154-66, 235-44.

4 Gadek JE, Kelman JA, Weinberger SE, et al. Collagenase in the lower respiratory tract of patients with idiopathic pulmonary fibrosis. N Engl J Med 1979;301:737-42.

5 Hunninghake GW, Gadek JE, Lawley TJ, et al. Mechanisms of neutrophil accumulation in the lungs of patients with idiopathic pulmonary fibrosis. J Clin Invest 1981;68:259-69.

6 Rudd RM, Haslam PL, Turner-Warwick M. Cryptogenic fibrosing alveolitis. Relationships of pulmonary physiology and bronchoalveolar lavage to response to treatment and prognosis. Am Rev Resp Dis 1981;124: 1-8.

7 Hunninghake GW, Moseley PL. Immunological abnormalities of chronic noninfectious pulmonary diseases. In: Bienenstock J, ed. Immunology of the lung and upper respiratory tract. New York: McGraw-Hill, 1984: 345-64.

8 Bitterman PB, Rennard SI, Hunninghake GW, et al. Human alveolar macrophage growth factor for fibroblasts. Regulation and partial characterization. $J$ Clin Invest 1982;70:806-22.

9 Watters LC, Schwarz MI, Cherniack RM, et al. Idiopathic pulmonary fibrosis. Pretreatment bronchoalveolar lavage cellular constituents and their relationships with lung histopathology and clinical response to therapy. Am Rev Respir Dis 1987;135: 696-704.

10 Hällgren R, Eklund A, Engström-Laurent A, Schmekel B. Hyaluronate in bronchoalveolar lavage fluid: a new marker in sarcoidosis reflecting pulmonary disease. $\mathrm{Br}$ Med J 1985;290:1778-81.

11 Bjermer L, Thunell M, Hällgren R. Procollagen III peptide in bronchoalveolar lavage fluid: a potential marker of altered collagen synthesis reflecting pulmonary disease in sarcoidosis. Lab Invest 1985;55:654-6.

12 Bjermer L, Engström-Laurent A, Thunell M, Hällgren R. Hyaluronic acid in bronchoalveolar lavage fluid in patients with sarcoidosis; relationship to lavage mast cells. Thorax 1987;42:933-8.

13 Bjermer L, Engström-Laurent A, Lundgren R, Rosenhall L, Hällgren R. Hyaluronate and type III procollagen peptide in bronchoalveolar lavage fluid as markers of disease activity in farmer's lung. $\mathrm{Br}$ Med J 1987; 295:803-6.

14 Berglund E, Birath G, Bjure J, et al. Spirometric studies in normal subjects. Acta Med Scand 1963;173:185-206.

15 Hinshaw HC, Murray JF, eds. Disease of the chest. Philadelphia: Saunders, 1980:141-2.

16 McLoud TC, Carrington CB, Gaensler EA. Diffuse infiltrative lung disease: a new scheme for description. Radiology 1983;149:353-63.

17 McLoud TC, Epler GR, Gaensler EA, et al. A radiographic classification for sarcoidosis. Physiologic correlation. Invest Radiol 1982;17:129-38.

18 Laurent KBG, Tengblad A. Determination of hyaluronate in biological samples by a specific radioassay technique. Anal Biochem 1980;109:386-94.

19 Rohde H, Vargas L, Hahn E, et al. Radioimmunoassay for type III procollagen peptide and its application to human liver disease. Eur J Clin Invest 1979;9:451-9.

20 Cantin AM, Boileau R, Bégin R. Increased procollagen
III aminoterminal peptide-related antigens and fibroblast growth signals in the lungs of patients with idiopathic pulmonary fibrosis. Am Rev Respir Dis 1988;137:572-8.

21 Low RB, Cutroneo KR, Davis GS, Giancola MS. Lavage type III procollagen $N$-terminal peptides in human pulmonary fibrosis and sarcoidosis. Lab Invest 1983;48:755-9.

22 Kirk JME, Bateman ED, Haslam PL, Laurent GL, Turner-Warwick M. Serum type III procollagen peptide concentration in cryptogenic fibrosing alveolitis and its clinical relevance. Thorax 1984;39:726-32.

23 Nettelbladt O, Berg J, Schenholm M, Tengblad A, Hällgren R. Accumulation of hyaluronan (hyaluronic acid) in the alveolar interstitial tissue in bleomycininduced alveolitis. Am Rev Respir Dis (in press).

24 Rennard SJ, Farrans VJ, Bradley KH, Crystal RG. Lung connective tissue. In: Witschi HP, ed. Mechanisms in respiratory toxicology. Boca Raton, Florida: CRC Reviews, 1981:115-53.

25 Sisson JC, Castor CW, Klavons JA. Connective tissue activation. XVIII-Stimulation of hyaluronic acid synthetase activity. J Lab Clin Med 1985;96:189-97.

26 Harnerman D, Wood DD. Interleukin I enhances synovial cell hyaluronate synthesis. Proc Soc Exp Biol Med 1984;177:205-10.

27 Yaron M, Yaron I, Wiletzki Zor U. Interrelationship between stimulation of prostaglandin $E$ and hyaluronate production by poly(I)-poly(C) and interferon in synovial fibroblast culture. Arthr Rheum 1978;21: 694-8.

28 Engström-Laurent A, Feltelius N, Hällgren R, Wasteson A. Elevated serum hyaluronate in scleroderma. An effect of growth factor induced activation of connective tissue cells? Ann Rheum Dis 1985;44:614-20.

29 Hance AJ, Crystal RG. The connective tissue of the lung. Am Rev Respir Dis 1975;112:657-63.

30 Turner-Warwick M, Haslam PL, Lukoszek A, et al. Cells, enzymes and interstitial lung disease. JR Coll Physicians Lond 1981;15:5-16.

31 Miller EJ. Biochemical characteristics and biological significance of the genetically-distinct collagens. $\mathrm{Mol}$ Cell Biochem 1976;13:165-92.

32 Rohde H, Vargas L, Hahn E, Kalbfleich H, Bruguera M, Timpl R. Radioimmunoassay for type III procollagen peptide and its application to human liver disease. Eur $J$ Clin Invest 1979;9:451-9.

33 Bjermer L, Engsrtröm-Laurent A, Thunell M, Hällgren $R$. The mast cell and signs of pulmonary fibroblast activation in sarcoidosis. Int Arch Allergy Appl Immunol 1987;82:298-301.

34 Martinet Y, Rom WN, Grotendorst GR, Martin GR, Crystal RG. Exaggerated spontaneous release of platelet-derived growth factor by alveolar macrophages from patients with idiopathic pulmonary fibrosis. N Engl J Med 1987;317:202-9.

35 Dreisen RB, Schwartz MI, Theofilopolus AN, et al. Circulating immune complexes in the idiopathic interstitial pneumonias. N Engl J Med 1978;298:353-7.

36 Lawrence EC, Martin RR, Blaese RM, et al. Increased bronchoalveolar Ig-secreting cells in interstitial lung disease. N Engl J Med 1980;302:1186-8.

37 Rennard SI, Hunninghake GW, Bitterman PB, et al. Production of fibronectin by the human alveolar macrophage: a mechanism for the recruitment of fibroblats to sites of tissue injury in the interstitial lung diseases. Proc Natl Acad Sci USA 1981;78:7147-51. 